\title{
PENGARUH PERUBAHAN DIMENSI TERHADAP NILAI ISOLASI PADA BRANCH LINE COUPLER
}

\author{
Yudi Barnadi \\ Jurusan Teknik Elektro Universitas Widyatama \\ Jl. Cikutra No.204A Bandung \\ yudi.barnadi@widyatama.ac.id
}

\begin{abstract}
Abstrak-. Luasnya perairan nasional menjadi tantangan tersendiri bagi pemerintah dalam upaya pengamanan wilayah laut dari tindakan pelanggaran hukum. Indonesia perlu mengawasi betul-betul wilayah yang paling rawan agar sumber daya ikan nasional bisa dinikmati oleh masyarakat. Caranya, pangkalan bagi kapal-kapal pengawas (KKP, Bakamla, TNI AL) perlu dibangun di wilayah tersebut. Salah satu upaya yang perlu dilakukan yaitu peningkatan pengawasan secara ketat pemerintah dengan cara meningkatkan keamanan sekaligus menyusun aturan yang tepat agar bisa mencegah terjadinya pelanggaran hukum. kemampuan TNI AL dan Polri untuk menjaga seluruh wilayah laut, maka mereka harus menggunakan radar pengawas pantai. Radar pulsa ini mempunyai gelombang elektromagnetik yang diputus secara berirama, dan hanya memiliki satu antena yang digunakan untuk mengirim dan menerima sinyal. Untuk mengirim dan menerima sinyal, radar ini membutuhkan pemisah yang disebut duplekser. Duplekser berfungsi untuk mengisolasi sinyal yang ditransmisikan dan sinyal yang diterima dan komponen utama dari duplexer adalah BranchLine Hybrid Coupler. Coupler memiliki parameter yang menunjukkan kinerja seperti: Return Loss, Power Coupling, Insertion Loss dan nilai isolasi. Dalam penelitian ini dilakukan penelitian untuk mengetahui pengaruh perubahan dimensi terhadap nilai isolasi pada Branch line coupler. Isolasi sangat penting karena mempengaruhi kinerja duplekser. Nilai yang lebih kecil semakin baik kinerja duplekser tersebut. Penelitian ini dilakukan dengan memodifikasi panjang dan lebar saluran impedansi Coupler. Branch-Line Coupler dirancang dalam bentuk mikrostrip dan difabrikasi menggunakan
\end{abstract}

substrat FR-4 yang memiliki konstanta dielektrik 4,6, tebal 1,3 mm, dan frekuensi operasi $3 \mathrm{GHz}$. Untuk mendapatkan nilai optimasi karakteristik isolasi, kanal impedansi harus dimodifikasi, yaitu panjang dan lebar seri lengan $\left(Z_{0}=50\right)$, panjang dan lebar seri lengan $\left(Z_{0}=35,35\right)$, dan panjang dan lebar lengan shunt $(Z 0=50)$. Hasil optimasi isolasi didapatkan $-67.786 \mathrm{~dB}$.

Kata Kunci : Radar, Frekuensi S-Band, Coupler dan Nilai Isolasi

\begin{abstract}
The extent of national waters is a challenge for the government in efforts to secure marine areas from unlawful acts. Indonesia needs to really monitor the most vulnerable areas so that the national fish resources can be enjoyed by the community. To do this, bases for surveillance ships (KKP, Bakamla, TNI AL) need to be built in the area. One of the efforts that need to be done is to increase strict government supervision by increasing security as well as developing appropriate rules in order to prevent violations of the law. the ability of the Navy and the National Police to guard the entire sea area, they must use coastal surveillance radar. This pulse radar has electromagnetic waves that are disconnected rhythmically, and has only one antenna that is used to transmit and receive signals. To send and receive signals, these radars need a splitter called a duplexer. The duplexer serves to isolate the transmitted signal and the received signal and the main component of the duplexer is the Branch-Line Hybrid Coupler. Couplers have parameters that indicate performance such as:
\end{abstract}


Return Loss, Power Coupling, Insertion Loss and insulation value. In this study, a study was conducted to determine the effect of dimensional changes on the insulation value of the Branch line coupler. Isolation is very important because it affects the performance of the duplexer. The smaller the value the better the performance of the duplexer. This research was conducted by modifying the length and width of the impedance Coupler line. Branch-Line Coupler designed. in the form of microstrips and fabricated using FR-4 substrate which has a dielectric constant of 4.6, a thickness of $1.3 \mathrm{~mm}$, and an operating frequency of $3 \mathrm{GHz}$. To get the optimal value for isolation characteristics, the impedance channel must be modified, namely the length and width of the arm series $\left(\mathrm{Z}_{0}=50\right)$, the length and width of the arm series $\left(Z_{0}=35.35\right)$, and the length and width of the shunt $\operatorname{arm}\left(Z_{0}=50\right)$. The isolation optimization result is $-67,786 \mathrm{~dB}$.

Keyword : Radar, S-Band frequency, Coupler and Isolation

\section{Pendahuluan}

Branch Line Coupler merupakan salah satu rangkaian gelombang mikro pasif yang penting, biasanya berfungsi sebagai pembagi atau penggabung daya pada suatu subsistem perangkat komunikasi atau radar [1]. Perangkat ini diimplementasikan dengan berbagai cara untuk memperoleh kemampuan. Branch Line Coupler umumnya terdiri dari empat port yang ideal, tidak memiliki kerugian dan timbal balik. Pada dasarnya Branch Line Coupler adalah perangkat pasif dengan empat terminal yang memiliki 4 buah lengan linier simetris untuk menghasilkan sinyal keluaran $90^{\circ}$ fasa yang berbeda [1]. Kinerja Branch Line Coupler ditentukan oleh parameter-parameter seperti: return loss, insertion loss, faktor kopling dan isolasi. Duplekser adalah salah satu implementasi dari Branch Line Coupler, duplekser merupakan salah satu bagian dari radar pulsa. Pada radar pulsa hanya memiliki satu antena yang digunakan untuk mengirim dan menerima sinyal. Pada [2] dijelaskan kemampuan duplekser untuk memisahkan sinyal yang ditransmisikan dan sinyal yang diterima

Branch Line Coupler konvensional pada dasarnya memiliki dimensi yang cukup besar dan memiliki nilai isolasi kurang dari $-20 \mathrm{~dB}$, pada frekuensi tinggi nilai isolasi ini $(-20 \mathrm{~dB})$ tidak dapat digunakan karena banyaknya sinyal dengan sudut fasa yang berbeda-beda [3]. Tujuan dari penelitian ini adalah untuk mendapatkan isolasi Branch Line Coupler yang lebih baik (kurang dari $55 \mathrm{~dB})$.
Pada penelitian lain, percobaan dengan menggunakan coupler mikrostrip paralel serupa telah banyak digunakan karena mudah dibuat dan memiliki bentuk yang sederhana [4]. Kelemahan dan kekuranganya isolasi dan direktivitas yang kurang baik karena konstanta dielektrik yang tidak homogen, menyebabkan perambatan gelombang mode ganjil pada jalur mikrostrip lebih cepat daripada mode genap [5]. Beberapa metode telah dilakukan untuk meningkatkan nilai isolasi coupler mikrostrip ini. Untuk mengurangi kecepatan fasa gelombang digunakan mode propagasi dielektrik

Untuk meningkatkan nilai isolasi coupler dilakukan juga dengan penambahan ukuran ground plane aperture, metode ini dapat memperbaiki isolasi pada coupler konvensional, namun karena kesulitan dalam fabrikasi, teknik ini tidak dapat dilakukan dalam bentuk MMIC [9/6] . Ada cara lain juga untuk menghasilkan nilai isolasi yang tinggi yaitu teknik modifikasi impedansi saluran seperti teknik feed forward yang dilakukan dengan memodifikasi dimensi $T$ junction Branch Line Coupler. Topik penelitian telah dipilih untuk mendapatkan ukuran yang sesuai yang dapat memberikan nilai isolasi terbaik. Branch Line Coupler terdiri lengan seri dan lengan paralel, lengan seri memiliki impedansi seri $\mathrm{Z}_{\mathrm{o}}=50$ dan $\mathrm{Z}_{\mathrm{o}}=35,35$ dan lengan paralel $\mathrm{Z}_{\mathrm{o}}=50$.

Pada frekuensi radio (RF) dan gelombang mikro diperlukan kecepatan yang tinggi. Aplikasi ini menawarkan integrasi tingkat tinggi untuk mengurangi ukuran, berat, dan konsumsi daya yang lebih rendah [3]. Komponen berupa Monolithic Microwave Integrated-Circuit (MMIC) [7] dan Multilayer thin-film multichip module technology (MCM-D) [8/8] yang terintegrasi berupa microstrip [6] dan $T / R$ switching sirkuit [9]. perlu dirancang integrasi komponen aktif dan pasif. Selain elemen lumped, elemen terdistribusi, seperti coupler saluran cabang, merupakan elemen penting yang diperlukan untuk diintegrasikan dalam sistem gelombang mikro. Namun, metode integrasi komponen tersebut di atas menghasilkan nilai isolasi yang rendah di bawah $-20 \mathrm{~dB}$. Pada aplikasi $\mathrm{Tx} / \mathrm{Rx}$ secara simultan dimana kemampuan untuk memisahkan sinyal antara sinyal yang ditransmisikan dan yang diterima, diperlukan isolasi yang tinggi karena sinyal yang diterima di port penerima seringkali sangat lemah[10]. 
Dalam [10], antena yang mengirim dan menerima sinyal dalam keadaan polarisasi yang berbeda. Hal ini untuk memperoleh sinyal yang tepat melalui pengirim dan penerima dalam satu frekuensi pembawa. Pada [11], branch line coupler digunakan sebagai pemisah antara pengirim dan penerima, branch-line membagi input daya coupler pada satu port menjadi dua port yang sama dengan beda fasa $+90^{\circ}$ atau $-90^{\circ}$. Ini dapat digunakan untuk memperoleh polarisasi melingkar sisi kanan (sisi kanan) dan sisi kiri dengan menggunakan dua input antena polarisasi silang. Pada [11] juga digunakan dua buah dioda kapasitansi variabel pada suatu rangkaian yang berguna sebagai penyetelan untuk mendapatkan frekuensi operasi yang diinginkan. Dari simulasi diperoleh peningkatan isolasi sebesar $-52 \mathrm{~dB}$ [12]. Modifikasi dimensi branchline coupler pada $\mathrm{T}$ junction dengan parameter fisik W50 $\Omega: 2.952 \mathrm{~mm}, \mathrm{~L} 50 \Omega: 15.2 \mathrm{~mm}$ dan $\mathrm{W} 35.35 \Omega: 5.14 \mathrm{~mm}, \mathrm{~L} 35.35 \Omega: 15.2 \mathrm{~mm}$ memiliki hasil simulasi diperoleh nilai isolasi sebesar $-31.185 \mathrm{~dB}$. Pada [13] digunakan bentuk patch-coupled patch directional coupled yang memiliki patch berbentuk elips dengan panjang lengan $22,5 \mathrm{~mm}$, konstanta dielektrik substrat 4003 C Rogers Ro 3,38 pada frekuensi kerja $2 \mathrm{GHz}$, memiliki isolasi $-45 \mathrm{~dB}$.

Pada penelitian ini, Branch-Line coupler diterapkan dalam bentuk mikrostrip dengan substrat yang digunakan adalah FR-4 yang memiliki konstanta dielektrik 4,6 dan ketebalan 1,3 mm dengan frekuensi operasi $3 \mathrm{GHz}$. Kami menggunakan FR-4 karena mudah didapatkan di pasaran. Untuk mendapatkan nilai isolasi terbaik, dilakukan optimasi coupler saluran transmisi dengan memodifikasi panjang dan lebar lengan seri $\left(Z_{\mathrm{o}}=50\right)$, panjang dan lebar lengan seri $\left(Z_{0}=35,35\right)$, panjang dan lebar lengan paralel $\left(Z_{\mathrm{o}}=50\right)$ menggunakan software CST 2014. Hasil optimasi simulasi nilai isolasi adalah $-67,786 \mathrm{~dB}$.

\section{LANDASAN TEORI}

Antena yang digunakan pada radap pulsa dapat digunakan sebagai transmitte rmaupun receiver. Sehingga satu antenna dapatdigunakan baik menerima atau mengirimkan sinyal.Properti penting pada $R F$-frontend atau antena yangdigunakan dalam suatu sistem dengan single carrierfrequency adalah kemampuannya untuk memisahkanantara sinyal yang ditransmisikan dengan sinyal yangdikirimkan Branch line coupler pada RF berguna sebagai pemisah antara transmitter dengan receiver. Branch line coupler, transmitter dan receiver dipisahkan oleh perbedaan fasa antara keduanya. Jumlah cabang nya ada dua, pada rangkaian branch line coupler ditambahankan rangkaian $T$-junction yang berfungsi sebagai kompensasi discontinuity yang terjadi pada microstrip.

Pada penelitian ini, jenis coupler yang dirancang adalah $3 \mathrm{~dB}$ branch line coupler, merupakan salah satu jenis dari hybrid coupler untuk aplikasi pada CPE WiMAX. Branch line coupler memiliki empat port. Port 1 adalah input port, port 2 dan 3 adalah output port, dan port 4 adalah isolated port. Properti dasar dari branch line coupler adalah membagi power input pada salah satu port menjadi dua output yang sama besar dengan beda fasa $+90^{\circ}$ atau $-90^{\circ}$. Perbedaan fasa kedua output inilah yang digunakan sebagai pemisah antara sinyal yang ditransmisikan dengan sinyal yang diterima. Dalam merancang suatu microstip, perlu ditentukan dahulu jenis substrat yang digunakan. Substrat yang digunakan pada penelitian ini adalah FR4 (evoksi) yang memiliki konstanta dielektrik bahan $\varepsilon r=4,6$. Ketebalan substrat yang akan dirancang adalah 1,6 mm.

Besarnya saluran impedansi untuk $Z_{o}$ adalah $50 \Omega$ dan untuk $\mathrm{Zo}_{\mathrm{o}} / \sqrt{2}$ adalah $35 \Omega$. Selanjutnya saluran impedansi ini diubah kedalam satuan panjang dan lebar. Dimensi length (L) pada coupler pada branch line dan series line biasanya dipilih $1 / 4$ dari desain wavelength-nya atau disebut quarterwavelength $(\mathrm{L}=\lambda / 4)$, ditunjukkan seperti pada Gambar 1. Quarter wavelength dapat dicari dengan menggunakan

\section{Perancangan}

Geometri dari coupler garis Cabang yang diusulkan ditunjukkan pada Gambar.1. Saluran konektor $50 \Omega$ yang dirancang pada substrat dielektrik FR 4 adalah 4,6 dengan ketebalan 1,3 mm

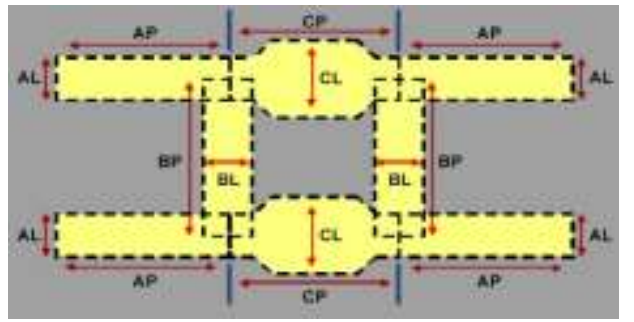

Gambar 1. Geometri dari Branch line Copuler [5]

Dimana :

AP = Panjang Saluran Transmisi (TL) A (mm) 
BP = Panjang Saluran Transmisi (TL) B (mm)

$\mathrm{CP}=$ Panjang Saluran Transmisi $(\mathrm{TL}) \mathrm{C}(\mathrm{mm})$

$\mathrm{AL}=$ Lebar Saluran Transmisi (TL) A (mm)

$\mathrm{BL}=$ Lebar Saluran Transmisi (TL) B (mm)

$\mathrm{CL}=$ Lebar Saluran Transmisi (TL) C (mm)

Penelitian ini diawali dengan menghitung dimensi pada rumus BLC konvensional. Perhitungan desain awal ini akan diperiksa dalam simulasi. Modifikasi dimensi BLC dilakukan sebagai cara untuk mendapatkan hasil simulasi yang optimal, kemudian akan dibuat desain yang optimum. BLC dirancang menggunakan $90^{\circ}$, dengan frekuensi resonansi pada $3 \mathrm{GHz}$

\section{Perancangan}

\section{a. Menghitung Panjang Saluran Transmisi}

Panjang Saluran Transmisi Kopler (L) adalah seperempat panjang gelombang propagasi pada material $[10,11]$ :

$$
\begin{aligned}
& \lambda g=\frac{c}{f \times \sqrt{g}} \\
& \lambda d=\frac{\lambda g}{4}
\end{aligned}
$$

Dimana $\mathrm{f}$ adalah frekuensi operasi, and $\varepsilon r$ adalah konstanta dielektrik dari substrat

b. Menghitung Lebar Saluran Transmisi

$$
\frac{W}{d}=\frac{8 \varepsilon^{a}}{a^{2 a}-2}
$$

Dimana $Z_{\mathrm{o}}$ adalah $50 \Omega$ and $35,35 \Omega$

$$
a=\frac{z_{0}}{6 D} \sqrt{\frac{s_{\gamma}+1}{2}}+\frac{s_{\gamma}-1}{s_{r}+1}\left(0.23+\frac{0.11}{s_{r}}\right)
$$

Dari perhitungan rumus diatas, diperoleh ukuran $\mathrm{AP}=\mathrm{BP}=\mathrm{CP}=11.66 \mathrm{~mm}, \mathrm{AL}=\mathrm{BL}=2.398 \mathrm{~mm}, \mathrm{CL}=$ $4.125 \mathrm{~mm}$

\section{c. Prosedur Optimasi}

Pengoptimasian coupler ini untuk mengetahui pengaruh perubahan panjang dan lebar saluran transmisi A, B dan $\mathrm{C}$ dari branch line coupler terhadap nilai isolasi.

Prosedur

1. Panjang saluran transmisi A (AP-1) dikurangi dari $11,66 \mathrm{~mm}, 11,55 \mathrm{~mm}, 11,50 \mathrm{~mm}, 11,48$ $\mathrm{mm}, 10,50 \mathrm{~mm}$ dan terakhir $10,48 \mathrm{~mm}$, tetapi panjang saluran transmisi $\mathrm{BP}, \mathrm{CP}$, dan lebar saluran transmisi saluran transmisi $\mathrm{Al}, \mathrm{BL}$ dan CL tidak mengalami perubahan (sama dengan nilai hasil perhitungan), hal ini dapat dilihat pada

\begin{tabular}{|c|c|c|c|c|c|c|c|c|}
\hline No & $\begin{array}{l}\text { AP-1 } \\
\text { (mm) }\end{array}$ & $\begin{array}{c}\text { BP } \\
\text { (mm) }\end{array}$ & $\begin{array}{c}\text { CP } \\
(\mathrm{mm})\end{array}$ & $\begin{array}{c}\text { AL. } \\
(\mathrm{mm})\end{array}$ & $\begin{array}{c}B t \\
(\mathrm{~mm})\end{array}$ & $\begin{array}{c}\mathrm{C} \\
(\mathrm{mm})\end{array}$ & $\begin{array}{l}\text { Freq } \\
\{[\mathrm{GHz}]\end{array}$ & $\begin{array}{l}S . A 1 \\
\text { (dB) }\end{array}$ \\
\hline 1 & 11.66 & 11.66 & 11.66 & 2.398 & 2.398 & 4.125 & 2814 & 34,366 \\
\hline 2 & 11.55 & 11.66 & 11.66 & 2.398 & 2.398 & 4.125 & 2816 & -34.159 \\
\hline 3 & 11.50 & 11.66 & 11.66 & 2.398 & 2.398 & 4.125 & 2817 & -34.009 \\
\hline 4 & 11.48 & 11.66 & 11.66 & 2.398 & 2.398 & 4.125 & 2818 & -33.947 \\
\hline 5 & 10.50 & 11.66 & 11.66 & 2.398 & 2.398 & 4.125 & 2819 & -30.031 \\
\hline
\end{tabular}
Tabel 1

Tabel 1. Pengaruh Pengurangan Panjang Sebaran Transmisi (AP-1)

2. Panjang saluran transmisi A (AP-2) dikurangi dari $10,45 \mathrm{~mm}, 10,40 \mathrm{~mm}, 10,38 \mathrm{~mm}, 10,37$ $\mathrm{mm}, 10,36 \mathrm{~mm}, 10,35 \mathrm{~mm}$, tetapi panjang saluran transmisi BP, CP, dan lebar saluran panjang $\mathrm{Al}, \mathrm{BL}$ dan $\mathrm{CL}$ tidak berubah (sama dengan nilai hasil perhitungan), ini dapat dilihat

\begin{tabular}{|c|c|c|c|c|c|c|c|c|}
\hline NO & $\begin{array}{l}\text { AP. } 2 \\
(\mathrm{~mm})\end{array}$ & $\begin{array}{c}\mathrm{BP} \\
\langle\mathrm{mm}\rangle\end{array}$ & $\begin{array}{c}C P \\
\text { (min) }\end{array}$ & $\begin{array}{c}\text { At } \\
(\mathrm{mm})\end{array}$ & $\begin{array}{c}B 2 \\
(\mathrm{~mm})\end{array}$ & $\underset{(\mathrm{mm})}{\mathrm{Cl}}$ & $\begin{array}{l}\text { Freq } \\
\text { (GHz) }\end{array}$ & $\begin{array}{l}5,41 \\
(d B)\end{array}$ \\
\hline 1 & 10.45 & 11.66 & 11.66 & 2.398 & 2.398 & 4.125 & 2.820 & -30.036 \\
\hline 2 & 10.40 & 11.66 & 11.66 & 2.398 & 2.398 & 4.125 & 2.823 & -30.014 \\
\hline 3 & 10,38 & 11.66 & 11.66 & 2,398 & 2.398 & 4.125 & 2824 & 30007 \\
\hline 4 & 10.37 & 11.66 & 11.66 & 2.398 & 2.398 & 4.125 & 2824 & -30.001 \\
\hline 5 & 10.36 & 11.66 & 11.66 & 2.398 & 2.398 & 4.125 & 2.824 & -29.996 \\
\hline 6 & 10.35 & 11.66 & 11.66 & 2.398 & 2.398 & 4.125 & 2824 & .29990 \\
\hline
\end{tabular}
pada Tabel 2

Tabel 2. Pengaruh Pengurangan Panjang Saluran Transmisi A (AP-2)

3. Panjang saluran transmisi A (AP-1) dan B (BP1) dikurangi, tetapi panjang saluran transmisi $C$ (CP), dan lebar saluran transmisi Al, BL dan CL tetap (sama dengan nilai hasil perhitungan), dapat dilihat Dimensi optimal dengan nilai isolasi terbaik yang diperoleh adalah 
pada saat $\mathrm{AP}-2=10,35 \mathrm{~mm}, \mathrm{BP}-2=10,36 \mathrm{~mm}$, $\mathrm{CP}-2=10,23 \mathrm{~mm}, \mathrm{AL}-2=2,78 \mathrm{~mm}, \mathrm{BL}-2=2,86$ $\mathrm{mm}$ dan CL-2 = 5.067pada tabel 3 .

Tabel 3. Pengaruh Pengurangan Panjang Saluran Transmisi B (BP-1)

\begin{tabular}{|c|c|c|c|c|c|c|c|c|}
\hline NO & $\begin{array}{c}\text { AP-1 } \\
(\mathrm{mm})\end{array}$ & $\begin{array}{c}\text { BP -1 } \\
(\mathrm{mm})\end{array}$ & $\begin{array}{c}\text { CP } \\
(\mathrm{mm})\end{array}$ & $\begin{array}{c}\text { AL } \\
(\mathrm{mm})\end{array}$ & $\begin{array}{c}\mathrm{BL} \\
(\mathrm{mm})\end{array}$ & $\begin{array}{c}\mathrm{C} \\
(\mathrm{mm})\end{array}$ & $\begin{array}{c}\text { Freq } \\
{[\mathrm{GH})}\end{array}$ & $\begin{array}{c}5.41 \\
(\mathrm{~dB})\end{array}$ \\
\hline 1 & 11.55 & $\mathbf{1 1 . 5 6}$ & 11.66 & 2.398 & 2.398 & 4.125 & 2.820 & $-34,286$ \\
\hline 2 & 11.50 & 11.50 & 11.66 & 2.398 & 2.398 & 4.125 & 2.825 & -34.266 \\
\hline 3 & 11.48 & 11.48 & 11.66 & 2.398 & 2.398 & 4.125 & 2.830 & -34.314 \\
\hline 4 & 10.50 & 10.50 & 11.66 & 2.398 & 2.398 & 4.125 & 2.862 & -33.966 \\
\hline 5 & 10.48 & 10.48 & 11.66 & 2.396 & 2.398 & 4.125 & 2.920 & 30.965 \\
\hline
\end{tabular}

4. Panjang saluran transmisi A (AP-2) dan B (BP2) dikurangi, tetapi panjang saluran transmisi $\mathrm{CP}$, dan lebar saluran transmisi $\mathrm{Al}, \mathrm{BL}$ dan $\mathrm{CL}$ tetap (sama dengan nilai hasil perhitungan), dapat dilihat pada tabel 4.

Tabel 4. Pengaruh Pengurangan Panjang Saluran Transmisi B (BP-2)

Tabet 4.Pragarab Progurangas Parjang Salurat Tranuade B(BP-2)

\begin{tabular}{|c|c|c|c|c|c|c|c|c|}
\hline NO & $\begin{array}{c}\text { AP-2 } \\
(\mathrm{mm})\end{array}$ & $\begin{array}{c}\text { BP -2 } \\
(\mathrm{mm})\end{array}$ & $\begin{array}{c}\text { CP } \\
(\mathrm{mm})\end{array}$ & $\begin{array}{c}\text { AL } \\
(\mathrm{mm})\end{array}$ & $\begin{array}{c}\text { BL } \\
(\mathrm{mm})\end{array}$ & $\begin{array}{c}\mathrm{CL} \\
(\mathrm{mm})\end{array}$ & $\begin{array}{c}\text { freq } \\
(\mathrm{GH})\end{array}$ & 5.41 (dB) \\
\hline 1 & 10.45 & 10.47 & 11.66 & 2.398 & 2.398 & 4.125 & 2.927 & -31.017 \\
\hline 2 & 10.40 & 10.46 & 11.66 & 2.398 & 2.398 & 4.125 & 2.930 & -31.007 \\
\hline 3 & 10.38 & 10.40 & 11.66 & 2.398 & 2.398 & 4.125 & 2.940 & -31.075 \\
\hline 4 & 10.37 & 10.38 & 11.66 & 2.398 & 2.398 & 4.125 & 2.942 & -31.060 \\
\hline 5 & 10.36 & 10.37 & 11.66 & 2.398 & 2.398 & 4.125 & 2.946 & -30.996 \\
\hline 6 & 10.35 & 10.36 & 11.66 & 2.398 & 2.398 & 4.125 & 2.950 & -30.881 \\
\hline
\end{tabular}

5. Panjang saluran transmisi A (AP-2) dan B (BP2) dikurangi, tetapi saluran transmisi $\mathrm{C}(\mathrm{CL}-1)$ bertambah dari 4.037, 4.200, 4.600, 4.600, 4.800, 4.900. Dari tabel di bawah ini terjadi peningkatan frekuensi dari $2.835 \mathrm{GHz}, 2.865$, $2.843 \mathrm{GHz}, 2.853 \mathrm{GHz}$, dan $2.948 \mathrm{GHz}$, ini terlihat pada tabel 5 .

Tabel 5. Pengaruh Penambahan Lebar Saluran Transmisi C (CL-1)

\begin{tabular}{|c|c|c|c|c|c|c|c|c|}
\hline NO & $\begin{array}{l}\text { AP.1 } \\
(\mathrm{mm})\end{array}$ & $\begin{array}{l}\text { BP - 1 } \\
\text { (mm) }\end{array}$ & $\begin{array}{l}\text { CP-1 } \\
(\mathrm{mm})\end{array}$ & $\begin{array}{l}\text { Al-1 } \\
\text { (mm) }\end{array}$ & $\begin{array}{l}\text { BL-1 } \\
\text { (mm) }\end{array}$ & $\begin{array}{l}\mathrm{C}-1 \\
(\mathrm{~mm})\end{array}$ & $\begin{array}{l}\text { Freq } \\
{[\mid \mathrm{GHz}]}\end{array}$ & $5.41(d B)$ \\
\hline 1 & 11.55 & 11.56 & 11.53 & 2.38 & 2.36 & 4.037 & 2.835 & -31.837 \\
\hline 2 & 11.50 & 11.50 & 12.43 & 2.48 & 2.40 & 4.200 & 2.865 & -27.474 \\
\hline 3 & 11.48 & 11.48 & 11.40 & 2.52 & 2.46 & 4.600 & 2843 & -28.583 \\
\hline 4 & 10.50 & 10.50 & 11.35 & 2.56 & 2.56 & 4.800 & 2853 & -35.082 \\
\hline 5 & 10.48 & 10.48 & 10.50 & 2.58 & 2.66 & 4.500 & 2.948 & -30756 \\
\hline
\end{tabular}

6. Panjang saluran transmisi A (AP-2), B (BP-2), C (CP-2) dikurangi, tetapi lebar saluran transmisi A (AL-2), B (BL-2) dan C ( CL-2) panjangnya bertambah dari $5.000 \mathrm{~mm}, 5.020 \mathrm{~mm}, 5.040 \mathrm{~mm}$, $5.050 \mathrm{~mm}, 5.060$ dan terakhir $5.067 \mathrm{~mm}$. tetapi lebar saluran transmisi C (CL) tidak diubah (sama dengan nilai hasil perhitungan), ini dapat dilihat pada tabel 6

Tabel 6. Pengaruh Penambahan Lebar Saluran Transmisi C (CL-2)

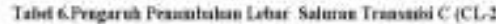

\begin{tabular}{|c|c|c|c|c|c|c|c|c|}
\hline NO & $\begin{array}{l}\text { AP-2 } \\
(\mathrm{mm})\end{array}$ & $\begin{array}{l}B P-2 \\
(\mathrm{~mm})\end{array}$ & $\begin{array}{l}\mathrm{CP}-2 \\
(\mathrm{~mm})\end{array}$ & $\begin{array}{l}\text { Al-2 } \\
\text { (mm) }\end{array}$ & $\begin{array}{l}8 \mathrm{l}-2 \\
(\mathrm{~mm})\end{array}$ & $\begin{array}{c}\mathrm{Cl}_{-2} \\
(\mathrm{~mm})\end{array}$ & $\begin{array}{l}\text { Freq } \\
{\left[\mathrm{GH}_{2}\right]}\end{array}$ & 5.41 (dB) \\
\hline 1 & 10.45 & 10,47 & 10.30 & 2.68 & 2.76 & 5.000 & 2.980 & -38.830 \\
\hline 2 & 10.40 & 10.46 & 10.28 & 2.70 & 2.80 & 5.020 & 2.980 & .38 .028 \\
\hline 3 & 10.38 & 10.40 & 10.26 & 2.75 & 2.83 & 5.040 & 2.998 & -45.658 \\
\hline 4 & 10.37 & 10.38 & 10.25 & 2.76 & 2.84 & 5.050 & 3.000 & $-48,058$ \\
\hline 5 & 10.36 & 10.37 & 10.24 & 2.77 & 2.85 & 5.060 & 3.000 & -51.042 \\
\hline 6 & 10.35 & 10.36 & 10.23 & 2.78 & 2,86 & 5.067 & 3,000 & -67.786 \\
\hline
\end{tabular}

Ukuran hasil optimalisasi dengan nilai isolasi yang tertinggi diperoleh adalah pada saat ukuran-ukuran AP-2 $=10,35 \mathrm{~mm}, \mathrm{BP}-2=10,36 \mathrm{~mm}, \mathrm{CP}-2=10,23$ $\mathrm{mm}, \mathrm{AL}-2=2,78 \mathrm{~mm}, \mathrm{BL}-2=2,86 \mathrm{~mm}$ dan $\mathrm{CL}-2=$ 5.067

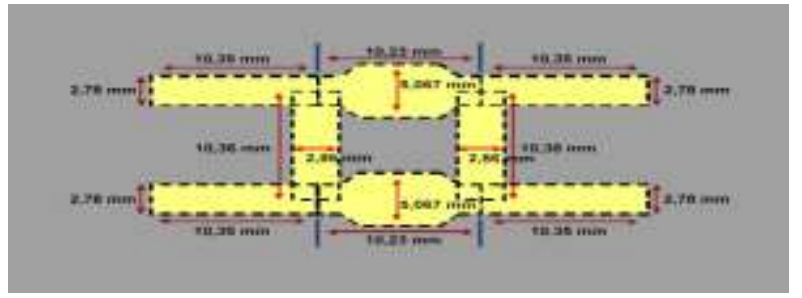

Gambar 2. Ukuran Branch line coupler hasil Optimalisasi dari

Hasil pabrikasi dari BLC dapat dilihat pada gambar bawah 3 .

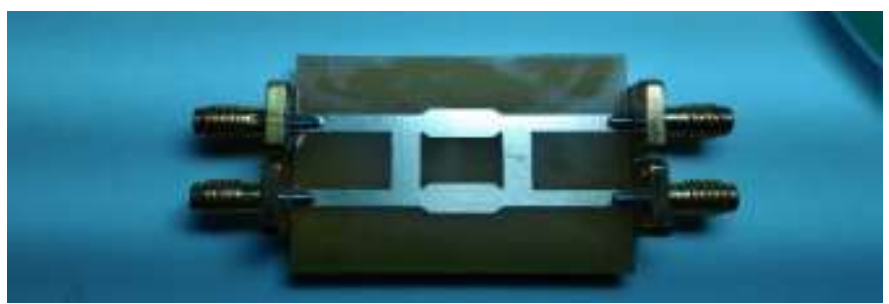

Gambar 3. Photo dari Branch Line coupler

Tabel 5. Pengaruh Penambahan Lebar Saluran Transmisi C (CL-1)
Yudi Barnadi

Jurnal Ilmiah Teknologi Informasi Terapan

Volume 8, No 1, 15 Desembar 2021 


\section{III.1 Hasil Simulasi}

Simulasi dilakukan setelah melakukan penghitungan danoptimasi. Hasilnya ditunjukkan pada Gambar 4 dan 5

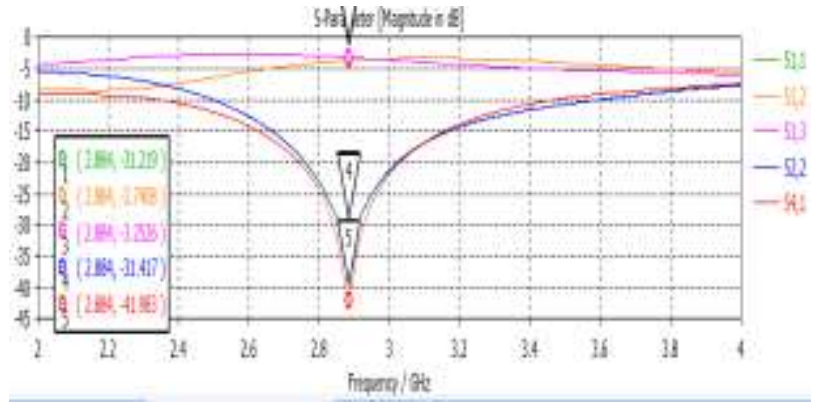

Gambar 4. Hasil Simulasi dari Perhitungan

Pada gambar 4 frekuensi operasi bergeser yang seharusnya $3 \mathrm{GHz}$ menjadi $2.884 \mathrm{GHz}$. Setelah optimasi dilakukan, hasilnya ditunjukan pada gambar 5 di bawah ini.

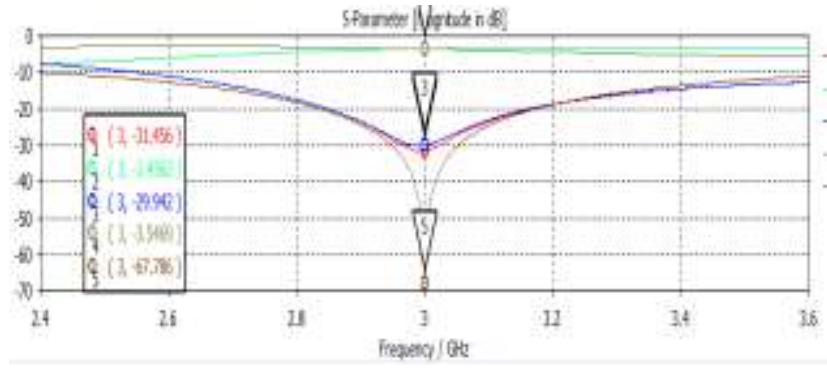

Gambar 5. Hasil Simulasi S parameter dari ukuran hasil optimalisasi

\section{III.2 Perbandingan ukuran hasil perhitungan dan optimasi}

Perbandingan ukuran BLC dari hasil perhitungan dengan hasil optimasi pada Tabel 7. Di bawah ini

Tabel 7. Perbandingan Ukuran BLC dari Hasil Perhitungan dengan Hasil Optimasi

Tabel 7. Perbandingan ukuran BLC dari hasil perhitungan
dengan hasil optimasi
\begin{tabular}{|l|l|l|}
\hline Variabel & UKuran Hasil Perhiturign & Uktiran hasil Optimasi \\
\hline AP & $11,66 \mathrm{~mm}$ & $10,35 \mathrm{~mm}$ \\
\hline AL & $2,398 \mathrm{~mm}$ & $2,78 \mathrm{~mm}$ \\
\hline BP & $11,66 \mathrm{~mm}$ & $10,36 \mathrm{~mm}$ \\
\hline BL & $2,398 \mathrm{~mm}$ & $2,86 \mathrm{~mm}$ \\
\hline CP & $11,66 \mathrm{~mm}$ & $10,23 \mathrm{~mm}$ \\
\hline CL & $4,125 \mathrm{~mm}$ & $5,067 \mathrm{~mm}$ \\
\hline
\end{tabular}

Tabel diatas merupakan ukuran-ukuran hasil menghitung dari rumus-rumus lalu di simulasikan. Dan ternyata terdapat pergeseran frekuensi.lalu berdasarkan dari ukuran tersebut di coba-coba ukurannya diubah-ubah supaya mendapatkan frekuensi $3 \mathrm{GHz}$

\section{KESIMPULAN DAN SARAN}

\section{V.1 KESIMPULAN}

Perubahan dimensi pada Branch line coupler akan mempengaruhi nilai isolasi dan bergesernya nilai frekuensi operasi. Perubahan yang sangat mempengaruhi nilai isolasi adalah perubahan lebar saluran transmisi yang memiliki lengan seri impedansi $Z o=35,35$. Untuk mendapatkan dimensi yang nilai isolasinya lebih baik dari $-55 \mathrm{~dB}$, dilakukan dengan menggunakan metode optimasi, terutama yang paling berpengaruh adalah optimasi . Isolasi terbaik dari BLC yang diperbaiki adalah $67,786 \mathrm{~dB}$.

\section{V.2 SARAN}

Melakukan penelitian Branch line coupler dengan -konstruksi atau geometri yang sama tetapi dengan frekuensi kerja yang berbeda dan spesifikasi yang berbeda dengan contoh material substrat Duroid sebelumnya

\section{REFERENSI}

W-d , Wirth. Radar Techniques Using Array Antennas. IEE, 2001

Skolnik, \& Merril, Radar Handbook,2nd. Boston., Mc Graw-Hill, 1990. Pages: 14.1 - 14.5

Byung-Jun Ahn, S.K Kim \& J.G Yook, "IsolationImproved Branch-line Coupler Based On Feedforward Technique", Dept of Electrical and Electronic Eng.Yonsei Univ. Korea , IEEE 2005

M. Moradian and M. Khalaj-Amirhosseini, "Improvement the Characteristic Of the Microstrip Parallel Couple line Coupler by means of Grooved Substrate", Dept of Electrical Engineering Iran University of Science and Technology Narmak, M, Vol. 3, 205-215, 2008

M. Moradian, "Improving isolation of slot-coupled directional couplers,"

Electronic Letters $11^{\text {th }}$, vol.51 No.12,pp 914915, June 2015
Yudi Barnadi

Jurnal Ilmiah Teknologi Informasi Terapan

Volume 8, No 1, 15 Desembar 2021 